\title{
Seasonal patterns of drinking water consumption pattern in Mysore City, Karnataka, South India
}

\author{
Jessen George and S. Suriyanarayanan
}

\begin{abstract}
The aim of this study is to determine the general drinking water consumption pattern in Mysore city, Karnataka, South India with special reference to cold water (without boiling), and to construct a data base for water consumption habits of Mysore people. In developing countries microbial risk assessment studies, water intake values are often adopted from developed countries. However, these values may not be suitable for the risk characterization of human populations from tropical regions of developing countries. Hence, the present study aimed to assess the water consumption pattern among the general population in Mysore city as a first attempt in this region. To compare seasonal variations in water consumption patterns, our study was carried in two major seasons, i.e. in the summer $(n=1,256)$ and winter $(n=1,230)$ of 2012-2013. Cold water intake rates were assessed by age, gender and season. The results of this study indicate that the average cold water consumption rate during the summer was $1.12 \mathrm{~L} /$ day per person and in the winter season was $0.92 \mathrm{~L} /$ day per person. The present survey study is believed to be the first attempt to quantify the intake of cold water consumption in Mysore city, Karnataka, South India.
\end{abstract}

Key words | cold water intake, drinking water, risk assessment, water consumption

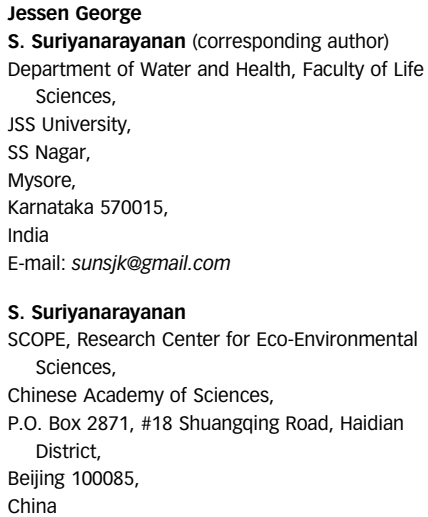

\section{INTRODUCTION}

The quality of drinking water is an essential determinant for better health (Popkin et al. 20IO). Contaminated drinking water serves as an important vehicle for transmitting diseases in humans. The associations between demographic characteristics and drinking water consumption patterns indicate potential differences in risk of exposure to waterborne pathogens in the population (Jones et al. 2006). In order to determine the microbial risk assessment from drinking water, both the dose of pathogens and the volume of consumed cold water are essential parameters (Mons et al. 2007). According to WHO and USEPA the standard quantity of water intake for adult was 2 litres per day and 1 litre per day for children. This standard quantity of drinking water may vary according to various environmental factors.

There are many factors, such as physiological and cultural issues, that may influence the water consumption doi: 10.2166/washdev.2016.082 pattern. It also varies according to different geographic locations and climate. The water consumption pattern may vary between countries (Westrell et al. 2006). It may be varied within the country based on the difference in climatic conditions, cultural differences, and demographic variables. Due to such differences in water intake levels the WHO suggested 'local adjustments' to set the local standard value for drinking water consumption rates (WHO 20II; Hossain et al. 20I3). In India drinking water consumption pattern studies seem to be very scarce and not much documentary evidence is on a survey scale. Therefore, it was necessary to carry out a water consumption survey in Mysore, Karnataka, South India.

Direct intake of drinking water leads to health hazard impacts mainly due to microbial and bacteriological impurities and the presence of pathogenic or disease 
producing bacteria. In recent years many studies have been carried out to determine the potential impact on health through drinking water consumption habits (Jarosinska et al. 2004; Lee et al. 2004; Watanabe et al. 2004; Ahsan et al. 2006; Jones et al. 2006; Milton et al. 2006; Westrell et al. 2006; Kile et al. 2007; Ohno et al. 2007; Xu et al. 2008; Barraj et al. 2009; Mondal et al. 2010; Kyunghee et al. 2010; Azlan et al. 2012; Hossain et al. 2013; Liangxin et al. 2014). To determine the risk of infection from waterborne pathogens, both water consumption rates and pathogen concentrations in drinking water are important parameters (Smeets et al. 2008). In developing countries microbial risk assessment studies water intake values are often adopted from developed countries. However, these values may not be suitable for the risk characterization of human populations from tropical regions of developing countries. Hence, the present study aimed to assess the water consumption pattern among the general population in Mysore city as a first attempt in this region.

The average cold water consumption rate was an important parameter to study the Quantitative Microbial Risk Assessment (QMRA) through drinking water. The first QMRA study on drinking water was carried out by Regli et al. (199I), who used the water consumption rate of $2 \mathrm{~L}$ per person per day. Later Roseberry \& Burmaster (I992) used the average value of $0.96 \mathrm{~L}$ per person per day. In the Netherlands Teunis et al. (1997) obtained data on average cold water consumption values at $0.153 \mathrm{~L}$ per person per day (Mons et al. 2007). The objective of this study is to assess the water consumption pattern among the general population in Mysore city. The data used in this study is based on the survey regarding the water consumption pattern in Mysore city during the period 20122013.

The aim of this study is to determine the general drinking water consumption pattern in Mysore city, Karnataka, South India with special reference to cold water (without boiling), and to construct a database for the water consumption habits of Mysore people. This study also focused on the demographic and seasonable variables. This study will be useful for further research on QMRA and calculate the burden of risk associated with the consumption of drinking water.

\section{MATERIALS AND METHODS}

\section{Study area}

The present study was carried out in an urban area of Mysore City Corporation. Mysore city covers an area of $128.42 \mathrm{~km}^{2}$ and is located at $12^{\circ} 18^{\prime} \mathrm{N} 76^{\circ} 39^{\prime} \mathrm{E}, 12.30^{\circ} \mathrm{N}$ $76.65^{\circ} \mathrm{E}$ and has an average altitude of $770 \mathrm{~m}$. The water supplies of Mysore are met by three water treatment plants (Jessen et al. 20I6). The total length of the distribution mains of these water treatment plants is about $1,281 \mathrm{~km}$, which supplies 125.98 MLD from the centralized Vani Vilas Water Works (Jessen et al. 2015).

\section{Water consumption pattern and demography}

The survey was carried out through a set of questionnaires. More than 600 questionnaires were handed over personally to the respondents. The survey was carried out during two seasons of the years 2012-2013 (winter and summer period). A total of 1,256 persons participated in the summer survey and 1,230 persons in the winter survey.

\section{Household selection}

A total of 1,256 persons from 300 families participated in the summer survey and 1,230 persons from 294 families participated in the winter survey. In the selection process, households having at least three members were included to ensure at least one adult male, one adult female, and a child from each household were study subjects.

The questionnaires contained questions on water intake mode such as cold water (water consumed directly as drinking water without boiling), type of water consumption (Cauvery water, bore well and bottled water) and volume of daily water consumption. Five alternatives were provided to determine the volume of cold water intake rate. They were less than 1, 1, 2, 3 and more than $3 \mathrm{~L}$, respectively.

The demographic variables considered in this study were age groups, gender and area of residence among the population of Mysore city. The city was divided into 65 
administrative wards. The coverage of water supply for domestic connection is about $67 \%$ in urban limits. The existing distribution of water to the city is not uniform in all areas and the total numbers of domestic tap water connection is about 0.13 million. Based on these proportions we segregated the study populations into six zones. They were Zone A (CSR-Vijayanagar), Zone B (GLSR), Zone C (Vani Vilas), Zone D (Kuvempu Nagar), Zone E (Devanur), and Zone $F$ (Yadava giri). The details of the demographic characteristics are shown in Table 1.

Table 1 | Demographic characteristics of participants

\begin{tabular}{|c|c|c|c|c|}
\hline \multirow[b]{2}{*}{$\begin{array}{l}\text { Demographic } \\
\text { characteristics }\end{array}$} & \multicolumn{2}{|c|}{ Summer survey $(n=1,256)$} & \multicolumn{2}{|c|}{ Winter survey $(n=1,230)$} \\
\hline & $\begin{array}{l}\text { Frequency } \\
\text { (n) }\end{array}$ & $\begin{array}{l}\text { Proportion } \\
\text { (\%) }\end{array}$ & $\begin{array}{l}\text { Frequency } \\
\text { (n) }\end{array}$ & $\begin{array}{l}\text { Proportion } \\
\text { (\%) }\end{array}$ \\
\hline \multicolumn{5}{|l|}{ Sex } \\
\hline Male & 632 & 50.3 & 618 & 50.2 \\
\hline Female & 624 & 49.7 & 612 & 49.8 \\
\hline \multicolumn{5}{|l|}{ Age group (year) } \\
\hline $0-9$ & 114 & 9.0 & 112 & 9.1 \\
\hline $10-19$ & 130 & 10.4 & 128 & 10.4 \\
\hline $20-29$ & 220 & 17.5 & 218 & 17.8 \\
\hline $30-39$ & 184 & 14.6 & 180 & 14.6 \\
\hline $40-49$ & 222 & 17.7 & 218 & 17.8 \\
\hline $50-59$ & 186 & 14.8 & 180 & 14.6 \\
\hline $60-69$ & 120 & 9.6 & 118 & 9.6 \\
\hline $70+$ & 80 & 6.4 & 76 & 6.1 \\
\hline \multicolumn{5}{|c|}{ Location of residence } \\
\hline Zone A & 358 & 28.6 & 350 & 28.5 \\
\hline Zone B & 226 & 18.0 & 220 & 17.9 \\
\hline Zone C & 84 & 6.7 & 80 & 6.5 \\
\hline Zone D & 168 & 13.3 & 166 & 13.4 \\
\hline Zone $\mathrm{E}$ & 168 & 13.3 & 164 & 13.3 \\
\hline Zone F & 252 & 20.1 & 250 & 20.3 \\
\hline \multicolumn{5}{|l|}{ Water source } \\
\hline $\begin{array}{l}\text { Municipal } \\
\text { supply }\end{array}$ & 1,030 & 82 & 1,028 & 83.5 \\
\hline $\begin{array}{l}\text { Bore well } \\
\text { water }\end{array}$ & 100 & 8 & 75 & 6.1 \\
\hline Bottled water & 126 & 10 & 127 & 10.4 \\
\hline Total & 1,256 & 100 & 1,230 & 100 \\
\hline
\end{tabular}

\section{RESULTS AND DISCUSSION}

\section{Characteristics of participants}

The demographic characteristics of participants are shown in Table 1. Participants were segregated according to their gender, age groups and place of living. A total of 1,256 persons from 300 families participated in the summer survey and 1,230 persons from 294 families participated in the winter survey. For all age groups, half of the participants were men and the remaining half were women.

In both surveys, about 19\% of the participants were less than 20 years of age, $65 \%$ were $20-59$ years old, and $16 \%$ of them were $60+$ years old.

The residence of surveyed populations was segmented into six zones. Zone A represents $28.5 \%$ of participants for both surveys. The subsequent zones represent 18, 6.6, 13.4, 13.3 and $20.2 \%$, respectively. In the summer survey $82 \%$ of participants depend on the municipal tap water supply and this increased by $1.5 \%$ during the winter survey. In the summer survey about $8 \%$ of participants depend on bore well water for drinking purposes and this decreased by $2 \%$ during the winter survey.

\section{Consumption of drinking water}

The cold water consumption rate is influenced by various factors including age, gender, and seasonal variables. The water consumption rates of eight age groups are presented in Tables 2 and 3. Out of 1,256 respondents in the summer survey $66.4 \%$ people answered that they drink cold water directly without boiling. In the winter survey,

Table 2 | Daily consumption of water among gender groups in Mysore City, South India

\begin{tabular}{|c|c|c|c|c|}
\hline \multirow{2}{*}{$\begin{array}{l}\text { Type of water } \\
\text { consumption } \\
\text { (L/day/person) }\end{array}$} & \multicolumn{2}{|c|}{ Summer survey $(n=1,256)$} & \multicolumn{2}{|c|}{ Winter survey $(n=1,230)$} \\
\hline & $\begin{array}{l}\text { Male }(n= \\
632)\end{array}$ & $\begin{array}{l}\text { Female }(n= \\
624)\end{array}$ & $\begin{array}{l}\text { Male }(n= \\
618)\end{array}$ & $\begin{array}{l}\text { Female }(n= \\
612)\end{array}$ \\
\hline $\begin{array}{l}\text { Municipal tap } \\
\text { water }\end{array}$ & 5 & 1. & 0.9 & 0.8 \\
\hline Bore w & 0.80 & 0.75 & 0.77 & $0.62 \pm 0.3$ \\
\hline Bottled water & $1.50 \pm 0.6$ & $1.30 \pm 0.3$ & $1.00 \pm 0.5$ & $1.00 \pm 0.4$ \\
\hline Average & $1.16 \pm 0.4$ & $1.03 \pm 0.3$ & $0.96 \pm 0.2$ & $0.88 \pm 0.2$ \\
\hline
\end{tabular}


Table 3 Average cold water intake (L/day) of the surveyed participants of Mysore city during summer

Age groups (years)

\begin{tabular}{|c|c|c|c|c|c|c|c|c|c|}
\hline \multirow[b]{2}{*}{ Type of water } & \multicolumn{8}{|c|}{ Age groups (years) } & \multirow[b]{2}{*}{$\begin{array}{l}\text { Total } \\
(n=834)\end{array}$} \\
\hline & $0-9(n=22)$ & $\begin{array}{l}10-19 \\
(n=54)\end{array}$ & $\begin{array}{l}20-29 \\
(n=186)\end{array}$ & $\begin{array}{l}30-39 \\
(n=166)\end{array}$ & $\begin{array}{l}40-49 \\
(n=142)\end{array}$ & $\begin{array}{l}50-59 \\
(n=122)\end{array}$ & $\begin{array}{l}60-69 \\
(n=86)\end{array}$ & $70+(n=56)$ & \\
\hline Municipal tap water & $0.65 \pm 0.5$ & $0.78 \pm 0.4$ & $1.7 \pm 0.6$ & $1.35 \pm 0.5$ & $1.8 \pm 0.5$ & $1.1 \pm 0.4$ & $0.86 \pm 0.3$ & $0.76 \pm 0.4$ & $1.125 \pm 0.4$ \\
\hline Bottled water & $0.5 \pm 0.4$ & $0.6 \pm 0.4$ & $2.0 \pm 0.5$ & $1.5 \pm 0.4$ & $2.0 \pm 0.5$ & $1.5 \pm 0.5$ & $1.0 \pm 0.5$ & $0.5 \pm 0.5$ & $1.2 \pm 0.6$ \\
\hline
\end{tabular}

out of 1,230 respondents $56.4 \%$ of people answered that they drink cold water during the winter period (Figure 1).

The total cold water consumption rate was greatest among the 20-29 and 40-49 age group and the consumption rate decreased in the $60+$ age group. Similar trends of results were also reported by Ershow \& Cantor (1989) and Kyunghee et al. (2010). In the studies carried out in western countries and colder regions, the authors reported that those aged 60+ years had a tendency to consume more water (USDA 1995; Westrell et al. 2006). This study noted that there was no clear trend associated with age in the consumption of cold water; however there was a tendency of decreasing water consumption in the $60+$ age group.

The water consumption rates among gender groups are summarized in Table 2. The water consumption rates for
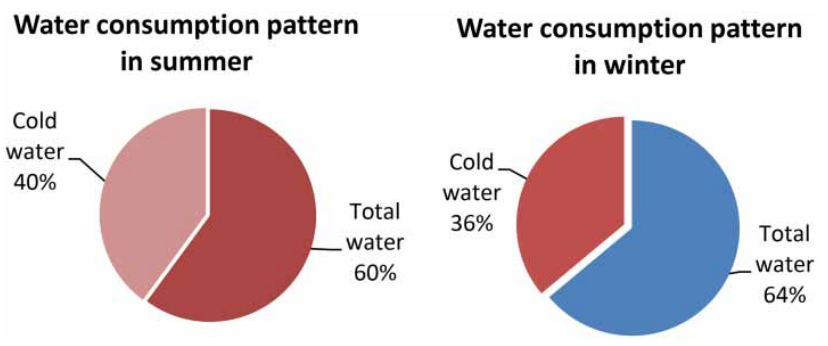

Figure 1 | Cold water consumption in summer and winter seasons males are greater than for females. This observation is comparable to EPA (2000), Levallois et al. (1998), Kyunghee et al. (2010) and Hossain et al. (2013). However, Gofti-Laroche et al. (200I) and Beaudeau et al. (2003) found that there was no significant difference between sexes. Our study clearly indicates that males consumed more water than females. This may be due to physical activity and body weight. The average body weight and height for Indian men is $64.0-68.5 \mathrm{~kg}$ and $1.700 \mathrm{~m}$, respectively, and 60.8-65.3 $\mathrm{kg}$ for women) (as compiled by the LIC of India and accepted as the standard weight chart for all of India).

The seasonal variations of water consumption rates are summarized in Tables 3 and 4. In summer, people tended to drink more water compared to the winter season. The average cold water consumption rate during summer was $1.12 \mathrm{~L} /$ day per person and in the winter season was $0.92 \mathrm{~L} /$ day per person. The seasons greatly affected the consumption of water. Our observation clearly shows that in the summer season people drink more cold water. Similar trends of observations were also reported by Gofti-Laroche et al. (200I), Xu et al. (2008) and Kyunghee et al. (2010).

The water intake rate is influenced by many factors. In recent years many studies have been carried out to determine the potential impacts of health through drinking water consumption habits. The mode of consumption of tap water (without boiling) varies between countries

Table 4 | Average cold water intake (L/day) of the surveyed participants of Mysore city during winter ${ }^{a}$

\begin{tabular}{|c|c|c|c|c|c|c|c|c|c|}
\hline \multirow[b]{2}{*}{ Type of water } & \multicolumn{8}{|c|}{ Age groups (years) } & \multirow[b]{2}{*}{ Total $(n=694)$} \\
\hline & $\begin{array}{l}\mathbf{0 - 9} \\
(n=18)\end{array}$ & $\begin{array}{l}10-19 \\
(n=46)\end{array}$ & $\begin{array}{l}20-29 \\
(n=162)\end{array}$ & $\begin{array}{l}30-39 \\
(n=136)\end{array}$ & $\begin{array}{l}40-49 \\
(n=114)\end{array}$ & $\begin{array}{l}50-59 \\
(n=108)\end{array}$ & $\begin{array}{l}60-69 \\
(n=62)\end{array}$ & $70+(n=48)$ & \\
\hline Municipal tap water & $0.6 \pm 0.4$ & $0.7 \pm 0.3$ & $1.4 \pm 0.4$ & $1.06 \pm 0.4$ & $1.16 \pm 0.4$ & $1.02 \pm 0.3$ & $0.78 \pm 0.4$ & $0.70 \pm 0.3$ & $0.92 \pm 0.3$ \\
\hline Bottled water & $0.5 \pm 0.3$ & $0.60 \pm 0.4$ & $1.5 \pm 0.5$ & $1.3 \pm 0.6$ & $1.6 \pm 0.4$ & $1.0 \pm 0.4$ & $1.0 \pm 0.5$ & $0.5 \pm 0.3$ & $1.00 \pm 0.4$ \\
\hline
\end{tabular}

a Municipal tap water and bottled water were included. 
(Table 5). Therefore our study intended to focus on the seasonal patterns of drinking water consumption.

\section{CONCLUSIONS}

The present survey study is believed to be the first attempt to quantify the intake of cold water consumption in Mysore city,
Karnataka, South India. The intake rate of cold water in Mysore was 66.4\% during summer and 56.4\% during winter. This proportion was higher when compared to other regions of the world. This may be due to lack of awareness about possible microbial contaminants in cold water. The limitation of our study was that it was performed over only a one-year period. To determine the water intake rate, the contributing factors are most important for any risk

Table 5 | Cold tap water intakes reported from other countries (L/day/person)

\begin{tabular}{|c|c|c|}
\hline Country and study population & Cold tap water & References \\
\hline England and Wales & 0.19 & Westrell et al. (2006) \\
\hline United Kingdom, $n=416$ & 0.70 & Hunter et al. (2004); Mons et al. (2007) \\
\hline United Kingdom, $n=421$ & 1.18 & Hunter et al. (2004); Mons et al. (2007) \\
\hline United Kingdom, $n=143^{\mathrm{a}}$ & 0.81 & Kaur et al. (2004) \\
\hline Canada, $\mathrm{n}=125$ & 0.386 & Levallois et al. (I998) \\
\hline $\mathrm{USA}, n=33^{\mathrm{b}}$ & 0.47 & Shimokura et al. (1998) \\
\hline USA, $n=15,303$ & $0.506^{\mathrm{c}}$ & USEPA (2000) \\
\hline $\mathrm{USA}, n=70^{\mathrm{a}}$ & 0.81 & USEPA (200o) \\
\hline Newzeland, $n=6,250$ & 0.17 & Mons et al. (2007) \\
\hline Netherlands & $0.153^{\mathrm{d}}$ & Westrell et al. (2006) \\
\hline Australia, $n=253$ & 0.99 & Robertson et al. (2000a, 200ob); Mons et al. (2007) \\
\hline Australia $(\text { Melb })^{\mathrm{e}} n=950$ & 0.84 & Robertson et al. (2000a, 200ob, 2002); Mons et al. (2007) \\
\hline Australia, $(\text { Adel })^{\mathrm{e}} n=644$ & 0.71 & Robertson et al. (2000a, 200ob, 2002); Mons et al. (2007) \\
\hline France (winter) & 0.77 & Gofti-Laroche et al. (200I) \\
\hline France (spring) & 0.90 & Gofti-Laroche et al. (200I) \\
\hline France, $n=1809$ & 0.27 & Beaudeau et al. (2003) \\
\hline Sweden, $n=35$ & 1.44 & Mons et al. (2007) \\
\hline Sweden, $n=40$ & 1.55 & Mons et al. (2007) \\
\hline Sweden, $n=157$ & 0.86 & Westrell et al. (2006) \\
\hline Denmark, $n=195$ & 0.5 & Dangendorf (2003); Mons et al. (2007) \\
\hline China & 1.75 & Xu et al. (2008); An et al. (20II) \\
\hline China & 2.72 & Duan et al. (20IO); Shumin et al. (20I2) \\
\hline Korea (spring) $n=1,092$ & 1.01 & Kyunghee et al. (20Io) \\
\hline Korea (summer) $n=1,148$ & 1.21 & Kyunghee et al. (2010) \\
\hline India, West Bengal & $3.12^{\mathrm{f}}$ & Hossain et al. (20I3) \\
\hline India, Karnataka, Mysore city (winter) & $0.92^{\mathrm{c}}$ & Present study \\
\hline India, Karnataka, Mysore city (summer) & $1.12^{\mathrm{c}}$ & Present study \\
\hline
\end{tabular}

${ }^{\text {a }}$ Studies carried out in pregnant women.

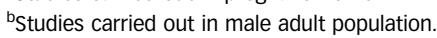

${ }^{c}$ Water supplied from the municipal water supply.

dMedian cold water consumption.

${ }^{\mathrm{e}}$ Study carried out in one city.

${ }^{\mathrm{f}}$ Mean direct water intake. 
assessment studies. Much of the water intake data are available from developed countries rather than developing countries. The current study of drinking water consumption pattern will be useful for further research on QMRA and calculate the burden of risk associated with the consumption of cold drinking water. Furthermore, this study also revealed the consumption of bottled water intake in Mysore, South India.

\section{ACKNOWLEDGEMENTS}

The authors are grateful to the volunteers in this study and also wish to thank the Authorities of Vani Vilas Water Works, Mysore, Govt. of Karnataka for their support in carrying out this study. We acknowledge the Indian Council of Medical Research (ICMR) (Project: 201214060) for financial support provided to the first author.

\section{REFERENCES}

Ahsan, H., Chen, Y., Parvz, F., Argos, M., Hussain, A. Z. M. I. \& Momotaj, H. 2006 Health effects of arsenic longitudinal study (HEALS): description of a multidisciplinary epidemiological investigation. J. Expo. Sci. Environ. Epidemiol. 16, 191-205.

An, W., Zhang, D., Xiao, S., Yu, J. \& Yang, M. 2oIr Quantitative health risk assessment of Cryptosporidium in rivers of southern China based on continuous monitoring data. Environ. Sci. Technol. 45 (11), 4951-4958.

Azlan, A., Khoo, H. E., Idris, M. A., Amin, I. \& Razman, M. R. 2012 Consumption perception on intake of drinking water in Klang Vally, Malaysia. Pak. J. Nutr. 11 (6), 584-590.

Barraj, L., Scrafford, C., Lantz, J., Daniels, C. \& Mihlan, G. 2009 Within-day drinking water consumption patterns: results from a drinking water consumption survey. J. Expo. Sci. Environ. Epidemiol. 19, 382-395.

Beaudeau, P., Zeghnoun, A., Ledrans, M. \& Volatier, J. L. 2003 Tap water consumption in France: results from the INCA1 diet survey. Environ. Risq. Sant. 2 (3), 147-158.

Dangendorf, F. 2003 Overview of the Drinking Water Supply Structure by Example of the Rheinisch. Thesis, Rheinischen Friedrich, Wilhelms, University, Bonn.

Duan, X. L., Wang, Z. S., Wang, B. B., Li, Y., Nie, J., Yu, Y. J. \& Zhang, J. L. 20Io Drinking water-related exposure factors in a typical area of Northern China. Res. Environ. Sci. 23 (9), 1216-1220.

EPA 2000 Estimated Per Capita Water Ingestion in the United States. EPA-822-R-00-008. Office of Water, USA.
Ershow, A. \& Cantor, K. I989 Total Water and Tap Water Intake in the United States: Population-based Estimates of Quantities and Sources. Life Sciences Research Office, Federation of American Societies for Experimental Biology, Bethesda, MD.

Gofti-Laroche, L., Potelon, J. L., Da Silva, E. \& Zrnirou, D. $200 \mathrm{I}$ Description of drinking water intake in French communities. Rev. Epidémiol. Sant. Publiq. 49 (5), 411-422.

Hossain, M. A., Rahman, M. M., Murrill, M., Das, B., Roy, B., Dey, S., Maity, D. \& Chakraborti, D. 2013 Water consumption patterns and factors contributing to water consumption in arsenic affected population of rural West Bengal, India. Sci. Total Environ. 1217 (24), 463-464.

Hunter, P. R., Hughes, S., Woodhous, Q., Syed, N. Q. \& Verlander, R. M. 2004 Sporadic cryptosporidiosis casecontrol study with genotyping. Emerg. Infect. Dis. 10 (7), 1241-1249.

Jarosinska, D., Peddada, S. \& Rogan, W. J. 2004 Assessment of lead exposure and associated risk factors in urban children in Silesia, Poland. J. Environ. Res. 95, 133-142.

Jessen, G., Wei, A., Dev, J., Dongqing, Z., Min, Y. \& Suriyanarayanan, S. 2015 Quantitative microbial risk assessment to estimate the health risk in urban drinking water systems of Mysore, Karnataka, India. Expo. Health $\mathbf{7}$ (3), 331-338.

Jessen, G., Divya, L., Magesh, S. B. \& Suriyanarayanan, S. 2016 An assessment of removal efficiency for the bacterial pathogens in Mysore urban water treatment system, Karnataka, India a case study. Desal. Water Treat. 57 (23), 10886-10893.

Jones, A. Q., Dewey, C. E., Dore, K., Majowicz, S. E., McEwen, S. A. \& Waltner-Toews, D. 2006 Drinking water consumption patterns of residents in a Canadian community. J. Water Health 4 (1), 125-138.

Kaur, S., Nieuwenhuijsen, M. J., Ferrier, H. \& Steer, P. 2004 Exposure of pregnant women to tap water related activities. Occup. Environ. Med. 61, 454-460.

Kile, M. L., Houseman, E. A., Breton, C. V., Quamruzzaman, Q., Rahman, M. \& Mahiuddin, G. 2007 Association between total ingested arsenic and biomarker response. J. Environ. Sci. Health A 42, 1827-1834.

Kyunghee, J., Younghee, K. \& Kyungho, C. 20Io Water intake rate among the general Korean population. Sci. Total Environ. 408, 734-739.

Lee, S. C., Guo, H., Lam, S. M. J. \& Lau, S. L. A. 2004 Multipathway risk assessment on disinfection by-products of drinking water in Hong Kong. J. Environ. Res. 94, 47-56.

Levallois, P., Guevin, N., Gingras, S., Levesque, B., Weber, J. \& Letarte, R. 1998 New patterns of drinking-water consumption: results of a pilot study. Sci. Total Environ. 209, 233-241.

Liangxin, F., Fei, W., Guobin, L., Xiaomei, Y. \& Wei, Q. 2014 Public perception of water consumption and its effects on water conservation behavior. Water 6, 1771-1784.

Milton, A. H., Rahman, H., Smith, W., Shrestha, R. \& Dear, K. 2006 Water consumption patterns in rural Bangladesh: are we underestimating total arsenic load? J. Water Health 4, 431-436. 
Mondal, D., Banerjee, M., Kundu, M., Banerjee, N., Bhattacharya, U. \& Giri, A. K. 2013 Comparison of drinking water, raw rice and cooking of rice as arsenic exposure routes in three contrasting areas of West Bengal, India. Environ. Geochem. Health 32, 463-477.

Mons, M. N., Van der Wielen, J. M. L., Blocker, E. J. M., Sinclair, M. I., Hulshof, F. A. M., Dangendorf, F., Hunter, P. R. \& Medema, G. J. 2007 Estimation of the consumption of cold tap water for microbiological risk assessment: an overview of studies and statistical analysis of data. J. Water Health 5 (1), 151-170.

Ohno, K., Yanase, T., Matsuo, Y., Kimura, T., Rahman, M. H. \& Magura, Y. 2007 Arsenic intake via water and food by a population living in an arsenic-affected area of Bangladesh. Sci. Total Environ. 381, 68-76.

Popkin, B. M., D’Anci, K. E. \& Rosenberg, I. H. 20Io Water, hydration and health. Nutr. Rev. 68 (8), 439-458.

Regli, S., Rose, J. B., Haas, C. N. \& Gerba, C. P. I99I Modelling the risk from Giardia and viruses in drinking water. J. Am. Water Works Assoc. 83 (11), 76-84.

Robertson, B., Forbes, A., Sinclair, M. \& Black, J. 20ooa How well does a telephone questionnaire measure drinking water intake? Aust. N. Z. J. Public Health 24 (6), 619-622.

Robertson, B., Sinclair, M. \& Forbes, A. 20oob The effect of an introductory letter on participation rates using telephone recruitment. Aust. N. Z. J. Public Health 24 (5), 552.

Robertson, B., Sinclair, M. I., Forbes, A. B., Veitch, M., Kirk, M., Cunliffe, D., Willis, J. \& Fairley, C. K. 2002 Case-control studies of sporadic cryptosporidiosis in Melbourne and Adelaide, Australia. Epidemiol. Infect. 128, 419-431.

Roseberry, A. M. \& Burmaster, D. E. 1992 Lognormal distributions for water intake by children and adults. Risk Anal. 12, 99-104.

Shimokura, G. H., Savitz, D. A. \& Symanski, E. 1998 Assessment of water use for estimating exposure to tap water contaminants. Environ. Health Perspect. 106 (2), 55-59.
Shumin, X., Wei, A., Zhimin, C., Dongqing, Z., Jianwei, Y. \& Min, Y. 2012 The burden of drinking water-associated cryptosporidiosis in China: the large contribution of the immunodeficient population identified by quantitative microbial risk assessment. Water Res. 46, 4272-4280.

Smeets, P. W., Dullemont, Y. J., Van Gelder, P. H., Van Dijk, J. C. \& Medema, G. J. 2008 Improved methods for modelling drinking water treatment in quantitative microbial risk assessment; a case study of Campylobacter reduction by filtration and ozonation. J. Water Health 6 (3), 301-314.

Teunis, P. F. M., Medema, G. J., Kruidenier, L. \& Havelaar, A. H. 1997 Assessment of the risk of infection by Cryptosporidium or Giardia in drinking water from a surface water source. Water Res. 31 (6), 1333-1346.

USDA 1995 Food and Nutrient Intakes by Individuals in the United States, 1 Day, 1989-1991. NFS Report No. 91-2. United States Department of Agriculture, Agricultural Research Service.

USEPA 2000 Estimated Per Capita Water Ingestion and Body Weight in the United States, An Update. U.S. Environmental Protection Agency, Office of Water, Office of Science and Technology, Wyashington, DC.

Watanabe, C., Kawata, A., Sudo, N., Sekiyama, M., Inaoka, T. \& Bae, M. 2004 Water intake in an Asian population living in arseniccontaminated area. Toxicol. Appl. Pharmacol. 198, 272-282.

Westrell, W., Anderson, Y. \& Stenstrom, T. A. 2006 Drinking water consumption patterns in Sweden. J. Water Health 4 (4), 511522.

WHO $20 \pi$ Guidelines for Drinking Water Quality, 4th edn. World Health Organization, Geneva.

Xu, P., Huang, S., Wang, Z. \& Lagos, G. 2008 Water consumption habit in General population of Shanghai and Beijing, China. Asian J. Ecotoxicol. 3, 224-230. 